\title{
Assessment of Antioxidant Defense System in Transplanted Rice Varieties (in Catalase and Nitrate Reductase)
}

\author{
Rita Tiwari ${ }^{1}$, S. P. Singh ${ }^{2}$ \\ ${ }^{1}$ Department of Botany, M.L.K. (P.G.) College Balrampur- 271201 (U.P.) India \\ ${ }^{2}$ Indian Institute of Sugarcane Research, Dilkusha, Lucknow-226 002 (U.P.), India
}

\begin{abstract}
Water loss in rice (Oryza sativa $L_{\text {.) }}$ can induce production of highly reactive molecules such as hydrogen peroxide $\left(\mathrm{H}_{2} \mathrm{O}_{2}\right)$ and hydroxyl radicals $(\mathrm{OH})$, singlet oxygen which all are named reactive oxygen species (ROS). ROS are regarded as main source of damage to cell of abiotic stress, which particularly synthesized in Chloroplast and Mitochondria salt tolerant varieties (Usar Dhan-3 and CSR-23 and salt susceptible varieties IR-42 and CSR-28) showed good result in stress condition increased or decreased under sodic condition in all salt tolerant varieties.
\end{abstract}

Keywords: Antioxidants, Oryza sativa L. , reactive oxygen species (ROS)

\section{Introduction}

Rice (Oryza sativa L.) is the most important cereal crop that provides $43 \%$ of calories requirement for more than $70 \%$ India as well as world population that is why the rice production always holds a key in the overall food situation of the whole world . In India, rice production was $217.28 \mathrm{mt}$ from 44\% mha cultivated area (Anonymous, 2008). In Uttar Pradesh, rice occupies an area of about 5-69 mha with production and productivity of $11.73 \mathrm{mt}$ tones and 20.62 q/ha resp. (Directorate of statistics, U.P. 2008).

The production always holds a key role in the over all food situation of the world, because it is the most important cereal crop that provides $43 \%$ of calories requirement for more than $70 \%$ India as well as world population. Water scarcity resulting from global climate change is accompanied by more frequent and more severe summer drought in many regions (Seneviratne fail., 2006; Kolves and Alexandra, 2008; Jaeger and Seneviratne, 2011). This cause drought stress in plants and limits crop yield world wide (Handy et al., 2003) The agricultural practice for drought tolerant crops turns into tropical demand (Cazanes et al., 2010). Water loss can induce production of highly reactive molecules such as hydrogen peroxide, superoxide anion and hydroxyl radicals, singlet oxygen which all are named reactive oxygen species (ROS). Plant response to drought is after acompained by oxidative damage (chaves et al., 2003; Noctor et al., 2002; Reddy et al., 2004; Slesak et al., 2007 and Foyer and Noctar, 2009). Antioxidant protection in plant cells is a complex and highly compartmentized phenomenon and includes both enzymatic and non-enzymatic components (Mittler, 2002).

ROS detoxifying enzymes are induced during different kinds of biotic and abiotic stresses for maintenance of normal growth. The key role of antioxidant enzymes is to reduce or scavenge ROS which are normally produced in different cell organelles and the cytosol. Their activities increase considerably under stress conditions Catalase and Nitrate reductase are the important ROS scavenging enzymes. They participate in removal of superoxide radical and hydrogen peroxide $\left(\mathrm{H}_{2} \mathrm{O}_{2}\right)$, produced directly or indirectly by Mehler reaction on and photorespiration in plants, preventing the formation of the highly toxic hydroxyl radical via Haberweiss or Fenton reactions (Mittler, 2002). Hydrogen peroxide was considered also as a signaling molecule involved in plant response to wide range of biotic and abiotic stresses. (Laloi et al., 2004). It was demonstrated that elevated levels of reactive oxygen species, such as hydroxyl radicals, under drought are capable to induced oxidative stress, causing lipid peroxidation and consequently membrane injury (Mittler, 2002). Plants with high levels of constitutive or induced antioxidants have been reported to have higher resistance to oxidative damage (Chaparzadeh et al., 2004; Feroj Lopez et al., 2009, 2010). The basic objective of the present work was, therefore, to investigate in details that how the biochemical enzymatic activities such as catalase, peroxidase and nitrate reductase are associated with sodicity tolerance in transplanted rice from transplanting to mature stage.

\section{Materials and Methods}

The present experiments were conducted for two Kharif seasons during 2010-2011 and 2011-2012. The investigations were carried out in either pot culture with four varieties/genotypes of rice (Oryza sativa L.) salt tolerant (Usar Dhan-3 and CSR-23) and salt sensitive IR-42 and CSR-28) at the experimental site of the Department of Botany, M.L.K. P.G. College, Balrampur in collaboration with Narendra Dev Uni. of agri. \& Tech, crop physiology Department, Kumarganj Faizabad under the supervision of Dr. S.P. Singh (Assis. Prof.). The experiments were laid out at four stages and two types of soil all in three replicates. The catalase activity was assayed with colorimeter according to the method described in Analytical Biochemistry (Sinha, 1972).

$200 \mathrm{mg}$. of fresh leaves were homogenized in $10 \mathrm{ml}$ of 0.1 $\mathrm{M}$ phosphate buffer ( $\mathrm{P}^{\mathrm{H}}$ 7.0) and centrifuged at 10,000 rpm 


\section{International Journal of Science and Research (IJSR) ISSN (Online): 2319-7064 \\ Index Copernicus Value (2013): 6.14 | Impact Factor (2015): 6.391}

for 30 minutes at $4^{0} \mathrm{c}$. The enzyme extract was stored at low temperature until assay.

The activity of enzyme was assayed by taking $1.25 \mathrm{ml} \mathrm{H}_{2} \mathrm{O}_{2}$, $0.5 \mathrm{ml}$ enzyme extract, $3.25 \mathrm{ml} 0.1 \mathrm{M}$ phosphate buffer $\left(\mathrm{P}^{\mathrm{H}} 7.0\right)$. The reaction mixture was taken in Erlenmeyer flask and mixed rapidly at $37^{\circ} \mathrm{C}$. at 3 minutes interval, $2.0 \mathrm{ml}$ of reaction mixture was withdrawn and poured into $4 \mathrm{ml}$ potassium dichromate acetic acid solution and kept in boiling water bath for $10 \mathrm{~min}$. The mixture was cooled and the colour intensity was measured at $570 \mathrm{~nm}$ on spectrophotometer against a reagent blank prepared similarly expect for the substitution of the enzyme extract with phosphate buffer.

Nitrate reductase (NR) assayed based on Methods described by Jaworski (1971). $250 \mathrm{Mg}$ of sample was suspended in screen cap vials having $4.5 \mathrm{ml}$ medium containing $0.1 \mathrm{M}$ phosphate buffer $\left(\mathrm{P}^{\mathrm{H}} 7.5\right) 0.02 \mathrm{M}$. $\mathrm{KNO}_{3} .5 \%$ propanol. A control was kept on omitting plant samples the vials were capped and kept in tank at $30^{\circ} \mathrm{C}$ for desired incubation period, Nitrate released into the medium was determined by treating $0.4 \mathrm{ml}$ aliquot with $0.3 \mathrm{ml}$ each of sulphanilamide and N-1 napthyl- ethylene diamine hydrochloride after 20 minutes the solution was diluted with distilled water to make the volume upto $5 \mathrm{ml}$ and the absorbance was measured at $540 \mathrm{~nm}$ using reagent blank standard curve was prepared using graded concentration of $\mathrm{NaNO}_{2}$ solution upto $100 \mathrm{ppm}$ and the amount of $\mathrm{NO}_{2}$ produced by the activity of nitrate reductase in the assay medium was calculated.

\section{RESULTS AND DISCUSSION}

In this study (Table-1) shows catalase activity increased under sodic soil in its tolerant varieties, i-e Usar Dhan-3. CSR-23 and in sensitive rice varieties IR-42 and CSR-28 corresponding to the days of 15, 45, 75 and maturity while Usar Dhan-3 shows highest catalase response and CSR-28 show minimum response. Salt tolerance has usually been assessed as the percentage of biomass production in saline versus control conditions over a prolonged period of time Nitrate reductase activity (Table-2) decreased at the age of corresponding to stages at $45 \mathrm{DAT}, 75 \mathrm{DAT}$ and at lowest at maturity stages.

In Nitrate reductase, highest enzyme content showed at 40 ESP. Plants possesses a number of antioxidant enzymes like NR and Catalase (CAT) to protect against the damaging effect of reactive oxygen species (ROS) (Asada, 1992 and Pal et al., 2004). Antioxidant enzymes play a significant role in rice plants is protect them against the damaging effect of Reactive oxygen species (ROS) generated during salinity stress (Asada, 1992)

Table 1: Catalase

\begin{tabular}{|c|c|c|c|c|c|c|c|c|c|c|c|c|c|c|c|c|c|c|c|c|}
\hline \multirow[t]{2}{*}{ Varieties } & \multicolumn{5}{|c|}{15 DAYS } & \multicolumn{5}{|c|}{45 DAYS } & \multicolumn{5}{|c|}{75 DAYS } & \multicolumn{5}{|c|}{ AT MATURITY } \\
\hline & S0 & S1 & S2 & S3 & Mean & S0 & S1 & S2 & S3 & Mean & S0 & S1 & S2 & S3 & Mean & S0 & S1 & S2 & S3 & Mean \\
\hline Usar & 330.34 & 337.2 & 347.5 & 361.3 & 344.1 & 420.1 & 428.8 & 442.0 & 459.5 & 437.6 & 475.4 & 485.3 & 500.2 & 520.0 & 495.3 & 365.1 & 372.7 & 384.2 & 399.42 & 380.40 \\
\hline Dhan-3 & & 2 & 4 & 1 & 0 & 2 & 7 & 0 & 1 & 3 & 9 & 9 & 5 & 7 & 0 & 8 & 9 & 0 & & \\
\hline \multirow[t]{2}{*}{ CSR-23 } & 3233.8 & 330.6 & 340.7 & 354.2 & 337.3 & 415.4 & 424.1 & 437.0 & 454.3 & 432.7 & 461.5 & 471.1 & 485.6 & 504.8 & 480.8 & 347.1 & 354.3 & 365.2 & 379.68 & 361.60 \\
\hline & 6 & 0 & 2 & 2 & 5 & 4 & 0 & 8 & 9 & 5 & 7 & 8 & 1 & 4 & 0 & 4 & 7 & 2 & & \\
\hline \multirow[t]{2}{*}{ IR-42 } & 285.10 & 297.2 & 309.3 & 324.5 & 304.0 & 357.1 & 372.3 & 387.5 & 406.4 & 380.8 & 386.3 & 402.7 & \begin{tabular}{|l|}
419.2 \\
\end{tabular} & 439.7 & 412.0 & 295.0 & 307.5 & 320.1 & 335.82 & 314.63 \\
\hline & & 3 & 7 & 3 & 6 & 1 & 0 & 0 & 9 & 5 & 4 & 8 & 2 & 7 & 3 & 2 & 7 & 3 & & \\
\hline \multirow[t]{2}{*}{ CSR-28 } & 281.06 & 293.0 & 304.9 & 319.9 & 299.7 & 351.6 & 366.5 & 381.5 & 400.2 & 374.9 & 379.9 & 396.1 & \begin{tabular}{|l|}
412.2 \\
\end{tabular} & 432.4 & 405.2 & \begin{tabular}{|l|}
288.0 \\
\end{tabular} & 300.2 & 312.5 & 327.862 & \\
\hline & & 2 & 8 & 3 & 5 & 1 & 7 & 3 & 3 & 9 & 5 & 2 & 8 & 9 & 1 & 3 & 8 & 4 & 307.187 & \\
\hline \multirow[t]{2}{*}{ Mean } & 305.09 & 314.5 & 325.6 & 340.0 & 321.3 & 386.0 & 397.9 & 412.0 & 430.1 & 406.5 & 425.8 & 438.8 & 454.3 & 474.2 & 448.3 & 323.8 & 33.75 & 345.5 & 360.69 & 340.95 \\
\hline & & 2 & 5 & 0 & 1 & 7 & 6 & 3 & 6 & 5 & 4 & 7 & 4 & 9 & 3 & 4 & & 2 & & \\
\hline SEm+ & \multicolumn{5}{|c|}{$\mathrm{V}=4.74, \mathrm{~S}=4.74, \mathrm{VXS}=9.49$} & \multicolumn{5}{|c|}{$\mathrm{V}=5.83, \mathrm{~S}=5.83, \mathrm{VXS}=11.67$} & \multicolumn{5}{|c|}{$\mathrm{V}=6.52, \mathrm{~S}=6.52, \mathrm{VXS}=13.03$} & \multicolumn{5}{|c|}{$\mathrm{V}=4.92, \mathrm{~S}=4.92, \mathrm{VXS}=9.83$} \\
\hline CD at $5 \%$ & \multicolumn{5}{|c|}{$\mathrm{V}=13.40, \mathrm{~S}=13.40, \mathrm{VXS}=\mathrm{NS}$} & \multicolumn{5}{|c|}{$\mathrm{V}=16.48, \mathrm{~S}=16.48, \mathrm{VXS}=\mathrm{NS}$} & \multicolumn{5}{|c|}{$\mathrm{V}=18.41, \mathrm{~S}=18.41, \mathrm{VXS}=\mathrm{NS}$} & \multicolumn{5}{|c|}{$\mathrm{V}=13.89, \mathrm{~S}=13.89, \mathrm{VXS}=\mathrm{NS}$} \\
\hline
\end{tabular}

Table 2: Nitrate reductase

\begin{tabular}{|c|c|c|c|c|c|c|c|c|c|c|c|c|c|c|c|c|c|c|c|c|}
\hline & \multicolumn{5}{|c|}{$15 \mathrm{DAT}$} & \multicolumn{5}{|c|}{45 DAT } & \multicolumn{5}{|c|}{$75 \mathrm{DAT}$} & \multicolumn{5}{|c|}{ AT MATURITY } \\
\hline Varieties & S0 & S1 & $\mathrm{S} 2$ & S3 & Mean & S0 & S1 & $\mathrm{S} 2$ & S3 & Mean & S0 & S1 & $\mathrm{S} 2$ & S3 & $\begin{array}{c}\text { Mea } \\
n\end{array}$ & S0 & S1 & $\mathrm{S} 2$ & S3 & Mean \\
\hline $\begin{array}{c}\text { USAR } \\
\text { DHAN - } \\
3\end{array}$ & 44.12 & 44.14 & 44.19 & 44.18 & 44.15 & 136.4 & 134.4 & 135.9 & 133.4 & 135 & 135.9 & $\begin{array}{c}133 . \\
7\end{array}$ & 134.9 & 132.7 & $\begin{array}{c}133 . \\
8\end{array}$ & 127.4 & 126.4 & 129.4 & 128.7 & 127.98 \\
\hline CSR-23 & 45.49 & 45.56 & 45.44 & 45.67 & 45.54 & 140.4 & 143.9 & 142.7 & 141.7 & 142.2 & 139.7 & $\begin{array}{c}142 . \\
7\end{array}$ & 141.7 & 140.7 & $\begin{array}{c}141 . \\
7\end{array}$ & $\begin{array}{c}128.1 \\
9\end{array}$ & 127.15 & 130.5 & 128.5 & 128.59 \\
\hline IR-42 & 42.19 & 42.43 & 42.61 & 42.44 & 42.41 & 130.4 & 128.4 & 132.4 & 129.4 & 130.2 & 129.1 & $\begin{array}{c}127 . \\
1\end{array}$ & 131.4 & 128.4 & $\begin{array}{c}129 . \\
0\end{array}$ & 11.14 & 115.12 & 109.12 & \begin{tabular}{|c|}
114.1 \\
2
\end{tabular} & 112.13 \\
\hline CSR-28 & 43.14 & 42.13 & 43.19 & 43.45 & 42.97 & \begin{tabular}{|c|}
132.9 \\
2 \\
\end{tabular} & 130.4 & 133.9 & 130.4 & 131.9 & 130.4 & $\begin{array}{c}130 . \\
1 \\
\end{array}$ & 132.7 & 130.4 & $\begin{array}{c}131 . \\
1\end{array}$ & 115.1 & 119.07 & 110.11 & \begin{tabular}{|c|}
112.1 \\
2 \\
\end{tabular} & 115.44 \\
\hline Mean & $\begin{array}{c}43.73 \\
5\end{array}$ & $\begin{array}{c}43.56 \\
5\end{array}$ & $\begin{array}{c}43.85 \\
7\end{array}$ & $\begin{array}{c}43.93 \\
5\end{array}$ & $\begin{array}{c}43.76 \\
7\end{array}$ & $\begin{array}{c}135.0 \\
3\end{array}$ & $\begin{array}{c}134.27 \\
5\end{array}$ & $\begin{array}{c}136.22 \\
5\end{array}$ & $\begin{array}{c}133.72 \\
5\end{array}$ & $\begin{array}{c}134.82 \\
5\end{array}$ & $\begin{array}{c}133.77 \\
5\end{array}$ & $\begin{array}{c}133 . \\
4\end{array}$ & $\begin{array}{c}135.17 \\
5\end{array}$ & $\begin{array}{c}133.0 \\
5\end{array}$ & $\begin{array}{c}133 . \\
9\end{array}$ & $\begin{array}{c}95.46 \\
2\end{array}$ & $\begin{array}{c}121.93 \\
5\end{array}$ & $\begin{array}{c}121.03 \\
5\end{array}$ & $\begin{array}{c}120.8 \\
6\end{array}$ & $\begin{array}{c}121.03 \\
5\end{array}$ \\
\hline $\mathrm{SE} \mathrm{m}^{+}$ & \multicolumn{5}{|c|}{$\mathrm{V}=0.35, \mathrm{~S}=0.35, \mathrm{VxS}=0.71$} & \multicolumn{5}{|c|}{$\mathrm{V}=0.8, \mathrm{~S}=0.8, \mathrm{VxS}=1.61$} & \multicolumn{5}{|c|}{$\mathrm{V}=0.75, \mathrm{~S}=0.75, \mathrm{VxS}=1.49$} & \multicolumn{5}{|c|}{$\mathrm{V}=0.84, \mathrm{~S}=0.84, \mathrm{VxS}=1.68$} \\
\hline $\begin{array}{c}\text { CD at } \\
5 \%\end{array}$ & \multicolumn{5}{|c|}{$\mathrm{V}=0.99, \mathrm{~S}=0 . \mathrm{NS}, \mathrm{VxS}=\mathrm{NS}$} & \multicolumn{5}{|c|}{$\mathrm{V}=2.20, \mathrm{~S}=\mathrm{NS}, \mathrm{VxS}=\mathrm{NS}$} & \multicolumn{5}{|c|}{$\mathrm{V}=2.12, \mathrm{~S}=\mathrm{NS}, \mathrm{VxS}=\mathrm{NS}$} & \multicolumn{5}{|c|}{$\mathrm{V}=2.38, \mathrm{~S}=2.38, \mathrm{VxS}=\mathrm{NS}$} \\
\hline
\end{tabular}




\section{References}

[1] Anonymous (2008). The Hindu Survey of Indian Agriculture.

[2] Chaves Maroco, J.P. and Pereiva, J.S. (2003). Understanding plant responses to drought from genes to whole plant. Functions to plant Biology, 30: 239-264

[3] Chapanzadeh, N.D., Anrico, M.L., Khavani Nejat, R.N., Izzo, R. and Navani-Izzo, F. (2004). Antioxidative responses of calendale officinalis under salinity conditions. Plant physiology Biochemistry, 695-701.

[4] Foyer, C.H. and Noctor, C. (2009). Redox regulation in photosynthetic organisms signaling, acclimation, and practical implications. Antioxid Redox Signal II : 862-878.

[5] Jaeger, E.B and Seneviratne, S.I. (2011). Impact of soil Moisture-atomosphere coupling on European climate extremes and trends in a regional climate mode climate dynamic 36 : 1919-1959.

[6] Koleva, E. and Alexandov, V. (2008). Drought in the Bulgarian low regions during the $20^{\text {th }}$ century theoretical applied climate. $92: 113-120$.

[7] Lalon, Cn Apel, K. and Danon, A. (2004). Reactive oxygen signaling the latest news current opinion. Plant Biology , 325-328.

[8] Mittler. R. (2002). Oxidative stress antioxidants and stress tolerance. Trends plant sciences 7:405-416.

[9] Noctor, G., Vebjivic-Javanovic S, Driscoll, S., Novitskauja, L. and Foyer, C.H. (2002). Drought and oxidative toad in the leaves of $\mathrm{C}_{3}$ plants; a predominant role for photorespiration Annal-Botany, $89: 84:-850$.

[10] Pal Madan Singh (2004). Photosynthetic characterstics and activity of antioxidant enzymes in salinity tolerant and sensitive rice cultivars. Indians of Plant physiol, 9 : 407-412.

[11] Pe'rez Lo' poz' U., Robredo, A., Lacu'a, M., sgherri, C., Man oz-Rueda, A., Navuri-Izzo, F. and Mena petite, A. (2009). The oxidative stress caused by salinity in two barley cultivars is mitigated by elevated $\mathrm{Co}_{2}$. Physiology plant, $135:$ 29-42.

[12] Reddy, R. A., Chaitanya, K. V. and Vivekanandan, M. (2004). Drought induced responses of photosynthesis and antioxidant metabolism in higher plants. Journal plant physiology. 161 : 1109-1202.

[13] Seneviratne, S.I., Luithi, D., Litschi, M. and Schar, C. L. (2006). Atmosphere coupling and climate change in Europe. Nature, 443 : 205-209.

[14] Slesak, I., Libik, M., Kavpinska, Karpinsiski, S. and Miszalski, Z. (2007). The role of hydrogen peroxide in regulation of plant metabolism and cellular signaling in response to environmental stresses. Acta Biochemi., 54: 39-50.

[15] Sinha, A.K. (1972). Colometric assay of catalase . Analytical biochemistry, 47:389-394. 